\title{
Physiologic Specialization of Puccinia triticina on Wheat in the United States in 2005
}

\author{
J. A. Kolmer, D. L. Long, and M. E. Hughes, USDA-ARS Cereal Disease Laboratory, Department of Plant Pathol- \\ ogy, University of Minnesota, St. Paul 55108
}

\begin{abstract}
Kolmer, J. A., Long, D. L., and Hughes, M. E. 2007. Physiologic specialization of Puccinia triticina on wheat in the United States in 2005. Plant Dis. 91:979-984.

Collections of Puccinia triticina were obtained from rust-infected wheat leaves by cooperators throughout the United States and from surveys of wheat fields and nurseries in the Great Plains, Ohio River Valley, southeast, California, and Washington State, in order to determine the virulence of the wheat leaf rust population in 2005. Single uredinial isolates (797 in total) were derived from the collections and tested for virulence phenotype on lines of Thatcher wheat that are near-isogenic for leaf rust resistance genes $L r 1, L r 2 a, L r 2 c, L r 3 a, L r 9, L r 16, L r 24, L r 26, L r 3 k a$, Lr11, Lr17a, Lr30, LrB, Lr10, Lr14a, Lr18, Lr21, Lr28, and winter wheat lines with genes Lr41 and $L r 42$. In the United States in 2005, 72 virulence phenotypes of P. triticina were found. Virulence phenotype TDBGH, selected by virulence to resistance gene $L r 24$, was the most common phenotype in the United States, and was found throughout the Great Plains region. Virulence phenotype MCDSB with virulence to Lr17a and Lr26 was the second most common phenotype and was found widely in the wheat growing regions of the United States. Virulence phenotype MFPSC, which has virulence to Lr17a, Lr24, and Lr26, was the third most common phenotype, and was found in the Ohio Valley region, the Great Plains, and California. The highly diverse population of $P$. triticina in the United States will continue to present a challenge for the development of wheat cultivars with effective durable resistance to leaf rust.
\end{abstract}

Additional keywords: epidemiology, Puccinia recondita f. sp. tritici, specific virulence

Leaf rust, caused by Puccinia triticina, is the most common and widespread disease of common bread wheat in the United States and worldwide (20). Yield losses in wheat caused by leaf rust occur on a yearly basis due to the regular occurrence of the disease and susceptible cultivars. Losses can vary from trace levels to over $20 \%$ depending on the stage of crop development when the initial infections occur and the relative resistance or susceptibility of the cultivar. In an early study, Caldwell et. al. (1) determined a range of yield losses from 15 to $28 \%$ due to leaf rust in susceptible soft red winter wheats. Most of the yield loss occurred due to a reduction in the number of kernels per head and by a reduction in kernel weight. In 1938, a leaf rust epidemic caused a 25 to $35 \%$ statewide yield loss in Oklahoma (2). In test plots with hard red spring wheat cultivars in Minnesota in 2004, yield losses in resistant cultivars were less than $10 \%$, while losses in susceptible cultivars varied from

Corresponding author: J. A. Kolmer

E-mail: jkolmer@umn.edu

Accepted for publication 7 March 2007.

doi:10.1094/PDIS-91-8-0979

This article is in the public domain and not copyrightable. It may be freely reprinted with customary crediting of the source. The American Phytopathological Society, 2007.
10 to $36 \%$ (J. A. Kolmer, unpublished data). In Kansas, from 1993 to 2005, losses due to leaf rust have averaged nearly $3.0 \%$, ranging from $11.0 \%$ in 1993 to trace levels of loss in 1996 and 2002 (USDAARS Cereal Disease Laboratory website). Chester (2) used data from 68 studies that examined yield loss in wheat due to leaf rust and developed a predictive curve for yield loss based on the growth stage in which defoliation due to rust occurred. In Chester's model, losses ranged from $10 \%$ if defoliation occurred in the dough stage of kernel development to $95 \%$ if defoliation occurred in the jointing stage. Khan et al. (7) used rust severity data and yield data from southern soft red winter wheats to develop a yield loss model that predicted a $1 \%$ yield loss for every $1 \%$ increase in rust severity at the milky-ripe stage of kernel development.

Similar estimates have been obtained for leaf rust yield losses on a worldwide basis. CIMMYT (International Center for Wheat and Maize Improvement) estimated an average loss of $3.7 \%$ over a 10 -year period for 22 developing countries (17). Yield losses due to leaf rust have also occurred recently in durum wheats. In experiments conducted in Mexico, Herrera-Foessel et al. (4) estimated yield losses of 51 and $26 \%$, respectively, for susceptible cultivars and cultivars with slow-rusting resistance to leaf rust. However, in general, yield losses averaged over large areas tend to be less than estimates obtained from experimental plots, since weather conditions, cultivar resistance, and frequency of fungicide applications can vary considerably over large wheat production areas.

In order to maintain high yields in wheat, it is essential to continually develop wheat cultivars that have effective resistance to leaf rust and other diseases. At CIMMYT, a benefit:cost ratio of $27: 1$ has been estimated for expenses related to development of wheat cultivars with leaf rust resistance (17). CIMMYT also determined that investment in breeding for leaf rust resistance would still be recovered even if yield losses in areas with high wheat yields were 0.2 to $0.8 \%$. The CIMMYT economic study indicated that protecting wheat yield potential through maintaining adequate leaf rust resistance can be equal to or greater than progress in maximizing yield potential.

At present, more than 50 leaf rust resistance genes have been described in wheat (18). Most of the genes condition racespecific resistance in a gene-for-gene relationship with $P$. triticina (21). As a result of the race specificity of resistance genes, wheat cultivars often lose their effective resistance in a short period of time due to the selection and increase of races with virulence to the specific resistance genes. The frequency of $P$. triticina isolates with virulence to a specific resistance gene can increase from less than $5 \%$ to over $60 \%$ of the population within a few years. The highly dynamic nature of leaf rust races in North America caused by the constant use of wheat cultivars with specific resistance genes has resulted in a highly diverse population of $P$. triticina. On an annual basis, 40 to 50 races of leaf rust are described in the United States (15). This high level of virulence diversity has made highly effective and long-lasting leaf rust resistance in wheat very difficult to achieve.

Virulence surveys of the wheat leaf rust fungus have been conducted by the USDAARS Cereal Disease Laboratory, formerly known as the Cereal Rust Laboratory, since 1978 to detect new virulence phenotypes and to monitor shifts of virulence phenotypes in the major wheat growing regions of the United States. Similar surveys have been done in Canada since 1931 $(5,8,9)$ and in Mexico $(22,23)$. In the United States (16) and Canada (10), data from leaf rust surveys have been used to 
characterize virulence, race dynamics, and phenotypic diversity within and between wheat growing regions. The objectives of this study were to characterize the virulence of $P$. triticina populations in the United States in 2005 to the North American wheat leaf rust differentials and to compare these results with those of previous surveys.

\section{MATERIALS AND METHODS}

Leaf rust occurrence and isolate collections. Uredinial collections of leaf rust were made from wheat plots and fields in surveys of the Great Plains, Ohio River Valley, southeastern states, and by cooperators throughout the United States. In 2005 , field surveys of wheat were made in southern and central Texas (late March); northern Texas and south-central Oklahoma (late April); the southeastern states of Louisiana, Alabama, Mississippi, and Georgia (late April to early May); Oklahoma and Kansas (late May); the Ohio River Valley states of Illinois, Indiana, and Ohio (early June); north central Kansas, Nebraska, western Iowa, South Dakota, and southern Minnesota (mid-June); and Minnesota, North Dakota, and South Dakota (early July and again in late July). Visual inspections for the presence of rust were made in commercial fields (4 to 50 hectares in size) every $32 \mathrm{~km}$ or in the first field thereafter. Additional collections were made in wheat breeding nurseries, trap plots, and demonstration plots along the route. Nurseries typically contain a wide array of breeding lines with various combinations of leaf rust resistance genes. Trap plots usually contain older, leaf rust susceptible wheat cultivars that are no longer prominent in commercial production. A collection consisted of one to several leaves with uredinia from a single plant or cultivar. The leaves were air-dried and stored at $4{ }^{\circ} \mathrm{C}$ until spores were collected for inoculation and increase. Collections from inoculated nurseries were not included in the study. Leaf rust was also collected from goat grass, Triticum cylin-

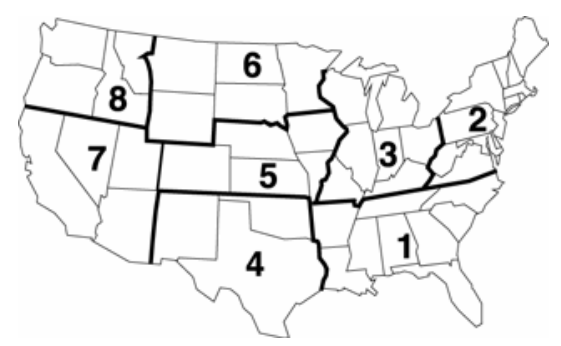

Fig. 1. Agroecological areas for Puccinia triticina in the United States. Area 1, mainly southern-adapted soft red winter wheats; areas 2 and 3, mostly northern-adapted soft red and white winter wheat; area 4 , mixed wheat types but primarily hard red winter; area 5 , hard red winter wheat; area 6 , mixed wheat types but primarily hard red spring and durum; area 7, spring wheats planted in late fall; area 8 , mixed wheat types but primarily soft white winter. dricum Ces. (=Aegilops cylindrica Host), growing near wheat fields in Texas, Oklahoma, and Kansas.

Identification of virulence phenotypes. Urediniospores from each collection were used to inoculate 7-day-old seedlings of the wheat cultivar Thatcher (CI 10003) that had been treated with a maleic hydrazide solution of approximately $0.01 \mathrm{~g}$ (dissolved in $30 \mathrm{ml} \mathrm{H}_{2} \mathrm{O}$ ) per pot to enhance spore production. Each pot of 10 to 20 seedlings was sprayed with $0.25 \mathrm{ml}$ of a suspension of spores in Soltrol 170 (Phillips Petroleum, Bartlesville, OK) mineral oil. After drying for $1 \mathrm{~h}$, inoculated plants were placed in a dew chamber overnight at $18^{\circ} \mathrm{C}$. The plants were then placed in individual plastic isolation chambers in a greenhouse where temperatures varied between 18 and $28^{\circ} \mathrm{C}$ daily under at least 8 $\mathrm{h}$ of natural light, with supplemental greenhouse lighting. After 12 to 15 days, three seedlings were saved per collection, each with the primary leaf trimmed to isolate a single uredinium. Six to 9 days later, a cyclone spore collector was used to collect urediniospores separately from one to three single uredinia per collection. If the single uredinia were small and few spores were collected, the isolates were increased through one uredinial generation on seedlings of Thatcher before inoculating differential lines. Otherwise, spores from the single uredinia were mixed with $0.25 \mathrm{ml}$ of oil and directly inoculated by atomization onto 7- to 8-day-old plants of the differential host series (five to seven plants per line) of near-isogenic lines of Thatcher wheat with single resistance genes Lrl, Lr2a, Lr2c, Lr3a, Lr3ka, Lr9, Lr10, Lr11, Lr14a, Lr16, Lr17a, Lr18, $L r 21, L r 24, L r 26, L r 28, L r 30$, and $L r B$, and winter wheat lines with $L r 41$ and $L r 42$. Wheat lines with genes $L r 1, L r 2 a$, $L r 2 c, L r 3 a$, and $L r 11$ were also in the early wheat leaf rust differential sets that were used in the United States and Canada from the $1930 \mathrm{~s}$ to the $1960 \mathrm{~s}(3,5,6)$. Sets of differential lines grown during June through September received no supplemental light. From October through May, natural daylight was supplemented with high-pressure sodium lamps from 0700 to $2300 \mathrm{~h}$ (400 to $450 \mu \mathrm{E} \mathrm{m} \mathrm{m}^{-2} \mathrm{~s}^{-1}$ at bench level). After 10 to 12 days, infection types (IT) were recorded as either high (IT 3 to 4) or low (IT 0 to $2^{+}$) as in previous surveys (15). A five-letter code describes the low or high infection types of each isolate to the 20 differential lines (14). Each letter corresponds to the infection types of four differentials. The Thatcher lines with genes $L r 1, L r 2 a, L r 2 c$, and $L r 3 a$ were the four lines in the first set of differentials; lines with genes $L r 9, L r 16, L r 24$, and $L r 26$ were the second set of differentials; lines with genes Lr3ka, LrI1, LrI7a, and Lr30 were the third set of differentials; and lines with genes $L r B, L r 10, L r 14 a$, and $L r 18$ were the fourth set of differentials; lines with genes
$L r 21, L r 28, L r 41$, and $L r 42$ were the fifth set of differentials. Sets 1 to 3 are the same as described by Long and Kolmer (14). The same first four sets of differentials have been used in $P$. triticina surveys in Canada (11). The fifth set of differentials was added for the first time in 2004 (13). Phenotype and virulence frequencies were determined for collections from eight agroecological geographic areas as shown and described in Figure 1.

\section{RESULTS}

Onset and spread of leaf rust. In the Great Plains, wheat leaf rust uredinia were first found in central Texas in late January. Temperature and moisture conditions in January and February allowed for development and spread of leaf rust throughout Texas. By mid-March, leaf rust was widespread in wheat fields throughout Texas. By mid-April, leaf rust was found in the hard red winter wheat region from Texas to Nebraska. In late April, cool temperatures slowed development of the leaf rust epidemic in Kansas and Nebraska. In late May, leaf rust was found in fields in northern Kansas. In the first week of June, leaf rust was found on winter wheat in southern Minnesota and in eastern South Dakota. In mid-June, leaf rust was found in winter wheat fields from southern Nebraska to North Dakota. Leaf rust was first found in spring wheat in Minnesota and South Dakota and North Dakota in mid-June. By mid-July, leaf rust was widespread in fields of spring wheat throughout South Dakota, North Dakota, and Minnesota.

In the southeastern United States, wheat leaf rust uredinia were first observed in late January in central Louisiana. By midFebruary, leaf rust was severe in wheat fields throughout Louisiana. By midMarch, leaf rust was widespread in southwestern Arkansas. In early April, leaf rust was present in the southern soft red winter wheat region from central Louisiana through Alabama and Georgia. By midMay, leaf rust was severe on susceptible wheat cultivars throughout the Gulf Coast region. In late April, leaf rust was present in North Carolina and Virginia. Leaf rust was present in fields from southern Illinois to northwestern Ohio in the northern soft red wheat region in early June. Leaf rust was found from Virginia to New York by mid-June. A complete summary of the 2005 leaf rust epidemic in the United States and losses due to leaf rust can be found at the USDA-ARS Cereal Disease Laboratory website.

Distribution of virulence phenotypes. A total of 72 virulence phenotypes of $P$. triticina were found in the United States from the 797 single uredinial isolates that were tested for virulence on the Thatcher lines (Table 1). Phenotypes TDBGH (10.4\%), MCDSB (8.5\%), and MFPSC $(8.2 \%)$ were the three most common phenotypes in the United States in 2005. 
Table 1. Number and frequency (\%) of virulence phenotypes of Puccinia triticina in the United States in 2005 identified by virulence to $20^{\mathrm{a}}$ lines of wheat with single genes for leaf rust resistance

\begin{tabular}{|c|c|c|c|c|c|c|c|c|c|c|c|c|c|c|c|c|c|c|c|}
\hline \multirow[b]{2}{*}{ Phenotype } & \multirow[b]{2}{*}{ Virulences } & & $\mathbf{a} 1^{b}$ & Are & $a 2^{c}$ & & $3^{d}$ & Are & $4^{e}$ & & $5^{f}$ & Are & $6^{9}$ & Are & & & $\mathbf{A}^{\mathrm{i}}$ & & \\
\hline & & $\#$ & $\%$ & $\#$ & $\%$ & $\#$ & $\%$ & $\#$ & $\%$ & $\#$ & $\%$ & $\#$ & $\%$ & $\#$ & $\%$ & $\#$ & $\%$ & $\#$ & $\%$ \\
\hline BBBDB & $14 \mathrm{a}$ & 1 & 0.6 & 0 & 0 & 0 & 0 & 0 & 0 & 0 & 0 & 1 & 0.4 & 0 & 0 & 0 & 0 & 2 & 0.3 \\
\hline MBBJG & $1,3,10,14 \mathrm{a}, 28$ & 0 & 0 & 0 & 0 & 0 & 0 & 0 & 0 & 0 & 0 & 0 & 0 & 0 & 0 & 2 & 25 & 2 & 0.3 \\
\hline MBDSB & $1,3,17, \mathrm{~B}, 10,14 \mathrm{a}$ & 6 & 3.8 & 2 & 8.3 & 3 & 11.1 & 9 & 4.1 & 1 & 1.5 & 6 & 2.2 & 7 & 35 & 1 & 12.5 & 35 & 4.4 \\
\hline MBJJG & $1,3,11,17,10,14 a, 28$ & 1 & 0.6 & 0 & 0 & 0 & 0 & 0 & 0 & 0 & 0 & 0 & 0 & 0 & 0 & 4 & 50 & 5 & 0.6 \\
\hline MBRKG & $1,3,3 \mathrm{ka}, 11,30,10,14 \mathrm{a}, 18,28$ & 12 & 7.6 & 0 & 0 & 0 & 0 & 0 & 0 & 2 & 2.9 & 0 & 0 & 0 & 0 & 0 & 0 & 14 & 1.8 \\
\hline MBSJB & $1,3,3 \mathrm{ka}, 11,17,10,14 \mathrm{a}$ & 0 & 0 & 0 & 0 & 0 & 0 & 0 & 0 & 0 & 0 & 0 & 0 & 2 & 10 & 0 & 0 & 2 & 0.3 \\
\hline MBTSB & $1,3,3 \mathrm{ka}, 11,17,30, \mathrm{~B}, 10,14 \mathrm{a}$ & 1 & 0.6 & 0 & 0 & 0 & 0 & 0 & 0 & 0 & 0 & 0 & 0 & 0 & 0 & 0 & 0 & 1 & 0.1 \\
\hline MCDSB & $1,3,26,17, \mathrm{~B}, 10,14 \mathrm{a}$ & 15 & 9.5 & 10 & 41.7 & 0 & 0 & 25 & 11.4 & 9 & 13.2 & 8 & 2.9 & 1 & 5 & 0 & 0 & 68 & 8.5 \\
\hline MCDSG & $1,3,26,17, \mathrm{~B}, 10,14 \mathrm{a}, 28$ & 0 & 0 & 0 & 0 & 0 & 0 & 2 & 0.9 & 0 & 0 & 1 & 0.4 & 2 & 10 & 1 & 12.5 & 6 & 0.8 \\
\hline MCPSC & $1,3,26,3 \mathrm{ka}, 17,30, \mathrm{~B}, 10,14 \mathrm{a}, 42$ & 2 & 1.3 & 0 & 0 & 0 & 0 & 0 & 0 & 0 & 0 & 0 & 0 & 0 & 0 & 0 & 0 & 2 & 0.3 \\
\hline MCRKG & $1,3,26,3 \mathrm{ka}, 11,30,10,14 \mathrm{a}, 18,28$ & 30 & 19 & 0 & 0 & 0 & 0 & 1 & 0.5 & 0 & 0 & 1 & 0.4 & 0 & 0 & 0 & 0 & 32 & 4 \\
\hline MCTSG & $1,3,26,3 \mathrm{ka}, 11,17,30, \mathrm{~B}, 10,14 \mathrm{a}, 28$ & 0 & 0 & 0 & 0 & 0 & 0 & 0 & 0 & 0 & 0 & 2 & 0.7 & 0 & 0 & 0 & 0 & 2 & 0.3 \\
\hline MDDSB & $1,3,24,17, \mathrm{~B}, 10,14 \mathrm{a}$ & 0 & 0 & 0 & 0 & 0 & 0 & 2 & 0.9 & 0 & 0 & 1 & 0.4 & 0 & 0 & 0 & 0 & 3 & 0.4 \\
\hline MDGJH & $1,3,24,11,10,14 a, 28,42$ & 0 & 0 & 2 & 8.3 & 0 & 0 & 0 & 0 & 0 & 0 & 0 & 0 & 0 & 0 & 0 & 0 & 2 & 0.3 \\
\hline MDNSB & $1,3,24,3 \mathrm{ka}, 17, \mathrm{~B}, 10,14 \mathrm{a}$ & 0 & 0 & 0 & 0 & 0 & 0 & 2 & 0.9 & 0 & 0 & 0 & 0 & 0 & 0 & 0 & 0 & 2 & 0.3 \\
\hline MFBJG & $1,3,24,26,10,14 a, 28$ & 0 & 0 & 2 & 8.3 & 2 & 7.4 & 0 & 0 & 0 & 0 & 0 & 0 & 0 & 0 & 0 & 0 & 4 & 0.5 \\
\hline MFDSB & $1,3,24,26,17, \mathrm{~B}, 10,14 \mathrm{a}$ & 0 & 0 & 0 & 0 & 0 & 0 & 8 & 3.6 & 0 & 0 & 0 & 0 & 0 & 0 & 0 & 0 & 8 & 1 \\
\hline MFGJG & $1,3,24,26,11,10,14 a, 28$ & 4 & 2.5 & 0 & 0 & 0 & 0 & 0 & 0 & 0 & 0 & 0 & 0 & 0 & 0 & 0 & 0 & 4 & 0.5 \\
\hline MFGJH & $1,3,24,26,11,10,14 a, 28,42$ & 8 & 5.1 & 0 & 0 & 0 & 0 & 0 & 0 & 0 & 0 & 0 & 0 & 0 & 0 & 0 & 0 & 8 & 1 \\
\hline MFPSB & $1,3,24,26,3 \mathrm{ka}, 17,30, \mathrm{~B}, 10,14 \mathrm{a}$ & 2 & 1.3 & 0 & 0 & 0 & 0 & 2 & 0.9 & 0 & 0 & 0 & 0 & 0 & 0 & 0 & 0 & 4 & 0.5 \\
\hline MFPSC & $1,3,24,26,3 \mathrm{ka}, 17,30, \mathrm{~B}, 10,14 \mathrm{a}, 42$ & 2 & 1.3 & 0 & 0 & 3 & 11.1 & 24 & 10.9 & 5 & 7.4 & 27 & 9.9 & 4 & 20 & 0 & 0 & 65 & 8.2 \\
\hline MFPSH & $1,3,24,26,3 \mathrm{ka}, 17,30, \mathrm{~B}, 10,14 \mathrm{a}, 28,42$ & 0 & 0 & 0 & 0 & 0 & 0 & 3 & 1.4 & 0 & 0 & 0 & 0 & 0 & 0 & 0 & 0 & 3 & 0.4 \\
\hline MHDSB & $1,3,16,26,17, \mathrm{~B}, 10,14 \mathrm{a}$ & 0 & 0 & 0 & 0 & 0 & 0 & 0 & 0 & 0 & 0 & 0 & 0 & 4 & 20 & 0 & 0 & 4 & 0.5 \\
\hline MJBJH & $1,3,16,24,10,14 \mathrm{a}, 28,42$ & 0 & 0 & 0 & 0 & 0 & 0 & 0 & 0 & 0 & 0 & 1 & 0.4 & 0 & 0 & 0 & 0 & 1 & 0.1 \\
\hline MLDSB & $1,3,9,17, \mathrm{~B}, 10,14 \mathrm{a}$ & 4 & 2.5 & 0 & 0 & 2 & 7.4 & 8 & 3.6 & 4 & 5.9 & 6 & 2.2 & 0 & 0 & 0 & 0 & 24 & 3 \\
\hline SBDBG & $1,2 \mathrm{a}, 2 \mathrm{c}, 17,28$ & 0 & 0 & 0 & 0 & 0 & 0 & 4 & 1.8 & 0 & 0 & 0 & 0 & 0 & 0 & 0 & 0 & 4 & 0.5 \\
\hline SBDDB & $1,2 \mathrm{a}, 2 \mathrm{c}, 17,14 \mathrm{a}$ & 0 & 0 & 0 & 0 & 0 & 0 & 1 & 0.5 & 2 & 2.9 & 1 & 0.4 & 0 & 0 & 0 & 0 & 4 & 0.5 \\
\hline TBBGG & $1,2 \mathrm{a}, 2 \mathrm{c}, 3,10,28$ & 6 & 3.8 & 0 & 0 & 0 & 0 & 0 & 0 & 0 & 0 & 2 & 0.7 & 0 & 0 & 0 & 0 & 8 & 1 \\
\hline TBBJG & $1,2 \mathrm{a}, 2 \mathrm{c}, 3,10,14 \mathrm{a}, 28$ & 1 & 0.6 & 0 & 0 & 0 & 0 & 4 & 1.8 & 3 & 4.4 & 9 & 3.3 & 0 & 0 & 0 & 0 & 17 & 2.1 \\
\hline TBDGH & $1,2 \mathrm{a}, 2 \mathrm{c}, 3,17,10,28,42$ & 0 & 0 & 0 & 0 & 0 & 0 & 0 & 0 & 0 & 0 & 2 & 0.7 & 0 & 0 & 0 & 0 & 2 & 0.3 \\
\hline TBDJG & $1,2 \mathrm{a}, 2 \mathrm{c}, 3,17,10,14 \mathrm{a}, 28$ & 0 & 0 & 0 & 0 & 0 & 0 & 0 & 0 & 2 & 2.9 & 4 & 1.5 & 0 & 0 & 0 & 0 & 6 & 0.8 \\
\hline TBDSB & $1,2 \mathrm{a}, 2 \mathrm{c}, 3,17, \mathrm{~B}, 10,14 \mathrm{a}$ & 3 & 1.9 & 0 & 0 & 0 & 0 & 3 & 1.4 & 0 & 0 & 1 & 0.4 & 0 & 0 & 0 & 0 & 7 & 0.9 \\
\hline TBDSG & $1,2 \mathrm{a}, 2 \mathrm{c}, 3,17, \mathrm{~B}, 10,14 \mathrm{a}, 28$ & 0 & 0 & 0 & 0 & 0 & 0 & 0 & 0 & 0 & 0 & 1 & 0.4 & 0 & 0 & 0 & 0 & 1 & 0.1 \\
\hline TBRKG & $1,2 \mathrm{a}, 2 \mathrm{c}, 3,3 \mathrm{ka}, 11,30,10,14 \mathrm{a}, 18,28$ & 12 & 7.6 & 0 & 0 & 0 & 0 & 0 & 0 & 0 & 0 & 0 & 0 & 0 & 0 & 0 & 0 & 12 & 1.5 \\
\hline TCBJG & $1,2 \mathrm{a}, 2 \mathrm{c}, 3,26,10,14 \mathrm{a}, 28$ & 0 & 0 & 0 & 0 & 0 & 0 & 2 & 0.9 & 0 & 0 & 0 & 0 & 0 & 0 & 0 & 0 & 2 & 0.3 \\
\hline TCRKG & $1,2 \mathrm{a}, 2 \mathrm{c}, 3,26,3 \mathrm{ka}, 11,30,10,14 \mathrm{a}, 18,28$ & 17 & 10.8 & 2 & 8.3 & 2 & 7.4 & 2 & 0.9 & 0 & 0 & 2 & 0.7 & 0 & 0 & 0 & 0 & 25 & 3.1 \\
\hline TCTDB & $1,2 \mathrm{a}, 2 \mathrm{c}, 3,26,3 \mathrm{ka}, 11,17,30,14 \mathrm{a}$ & 0 & 0 & 0 & 0 & 0 & 0 & 1 & 0.5 & 0 & 0 & 0 & 0 & 0 & 0 & 0 & 0 & 1 & 0.1 \\
\hline TDBGG & $1,2 \mathrm{a}, 2 \mathrm{c}, 3,24,10,28$ & 2 & 1.3 & 0 & 0 & 4 & 14.8 & 10 & 4.5 & 8 & 11.8 & 10 & 3.7 & 0 & 0 & 0 & 0 & 34 & 4.3 \\
\hline TDBGH & $1,2 \mathrm{a}, 2 \mathrm{c}, 3,24,10,28,42$ & 4 & 2.5 & 0 & 0 & 0 & 0 & 32 & 14.5 & 17 & 25 & 30 & 11 & 0 & 0 & 0 & 0 & 83 & 10.4 \\
\hline TDBJG & $1,2 \mathrm{a}, 2 \mathrm{c}, 3,24,10,14 \mathrm{a}, 28$ & 0 & 0 & 0 & 0 & 2 & 7.4 & 7 & 3.2 & 2 & 2.9 & 2 & 0.7 & 0 & 0 & 0 & 0 & 13 & 1.6 \\
\hline TDBJH & $1,2 \mathrm{a}, 2 \mathrm{c}, 3,24,10,14 \mathrm{a}, 28,42$ & 0 & 0 & 0 & 0 & 2 & 7.4 & 0 & 0 & 0 & 0 & 0 & 0 & 0 & 0 & 0 & 0 & 2 & 0.3 \\
\hline TDDGH & $1,2 \mathrm{a}, 2 \mathrm{c}, 3,24,17,10,28,42$ & 0 & 0 & 0 & 0 & 0 & 0 & 0 & 0 & 0 & 0 & 9 & 3.3 & 0 & 0 & 0 & 0 & 9 & 1.1 \\
\hline TDDJH & $1,2 \mathrm{a}, 2 \mathrm{c}, 3,24,17,10,14 \mathrm{a}, 28,42$ & 0 & 0 & 0 & 0 & 0 & 0 & 0 & 0 & 0 & 0 & 9 & 3.3 & 0 & 0 & 0 & 0 & 9 & 1.1 \\
\hline TDMJG & $1,2 \mathrm{a}, 2 \mathrm{c}, 3,24,3 \mathrm{ka}, 30,10,14 \mathrm{a}, 28$ & 0 & 0 & 0 & 0 & 0 & 0 & 2 & 0.9 & 0 & 0 & 0 & 0 & 0 & 0 & 0 & 0 & 2 & 0.3 \\
\hline TFBGH & $1,2 \mathrm{a}, 2 \mathrm{c}, 3,24,26,10,28,42$ & 0 & 0 & 0 & 0 & 2 & 7.4 & 5 & 2.3 & 0 & 0 & 3 & 1.1 & 0 & 0 & 0 & 0 & 10 & 1.3 \\
\hline TFBJG & $1,2 \mathrm{a}, 2 \mathrm{c}, 3,24,26,10,14 \mathrm{a}, 28$ & 0 & 0 & 2 & 8.3 & 1 & 3.7 & 7 & 3.2 & 0 & 0 & 0 & 0 & 0 & 0 & 0 & 0 & 10 & 1.3 \\
\hline TFDJH & $1,2 \mathrm{a}, 2 \mathrm{c}, 3,24,26,17,10,14 \mathrm{a}, 28,42$ & 2 & 1.3 & 0 & 0 & 0 & 0 & 0 & 0 & 0 & 0 & 0 & 0 & 0 & 0 & 0 & 0 & 2 & 0.3 \\
\hline TFDSB & $1,2 \mathrm{a}, 2 \mathrm{c}, 3,24,26,17, \mathrm{~B}, 10,14 \mathrm{a}$ & 0 & 0 & 0 & 0 & 0 & 0 & 2 & 0.9 & 0 & 0 & 0 & 0 & 0 & 0 & 0 & 0 & 2 & 0.3 \\
\hline TGBGH & $1,2 \mathrm{a}, 2 \mathrm{c}, 3,16,10,28,42$ & 0 & 0 & 0 & 0 & 0 & 0 & 0 & 0 & 0 & 0 & 3 & 1.1 & 0 & 0 & 0 & 0 & 3 & 0.4 \\
\hline TGBJG & $1,2 \mathrm{a}, 2 \mathrm{c}, 3,16,10,14 \mathrm{a}, 28$ & 0 & 0 & 0 & 0 & 0 & 0 & 0 & 0 & 0 & 0 & 13 & 4.8 & 0 & 0 & 0 & 0 & 13 & 1.6 \\
\hline TGDGG & $1,2 \mathrm{a}, 2 \mathrm{c}, 3,16,17,10,28$ & 0 & 0 & 0 & 0 & 0 & 0 & 0 & 0 & 0 & 0 & 11 & 4 & 0 & 0 & 0 & 0 & 11 & 1.4 \\
\hline TGDJG & $1,2 \mathrm{a}, 2 \mathrm{c}, 3,16,17,10,14 \mathrm{a}, 28$ & 0 & 0 & 0 & 0 & 0 & 0 & 0 & 0 & 0 & 0 & 1 & 0.4 & 0 & 0 & 0 & 0 & 1 & 0.1 \\
\hline TGDSB & $1,2 \mathrm{a}, 2 \mathrm{c}, 3,16,17, \mathrm{~B}, 10,14 \mathrm{a}$ & 0 & 0 & 0 & 0 & 2 & 7.4 & 0 & 0 & 0 & 0 & 1 & 0.4 & 0 & 0 & 0 & 0 & 3 & 0.4 \\
\hline TGDSG & $1,2 \mathrm{a}, 2 \mathrm{c}, 3,16,17, \mathrm{~B}, 10,14 \mathrm{a}, 28$ & 0 & 0 & 0 & 0 & 0 & 0 & 0 & 0 & 0 & 0 & 8 & 2.9 & 0 & 0 & 0 & 0 & 8 & 1 \\
\hline TGLJG & $1,2 \mathrm{a}, 2 \mathrm{c}, 3,16,3 \mathrm{ka}, 10,14 \mathrm{a}, 28$ & 4 & 2.5 & 0 & 0 & 0 & 0 & 0 & 0 & 0 & 0 & 0 & 0 & 0 & 0 & 0 & 0 & 4 & 0.5 \\
\hline THBJG & $1,2 \mathrm{a}, 2 \mathrm{c}, 3,16,26,10,14 \mathrm{a}, 28$ & 0 & 0 & 0 & 0 & 0 & 0 & 0 & 0 & 2 & 2.9 & 2 & 0.7 & 0 & 0 & 0 & 0 & 4 & 0.5 \\
\hline TJBGG & $1,2 \mathrm{a}, 2 \mathrm{c}, 3,16,24,10,28$ & 0 & 0 & 0 & 0 & 0 & 0 & 0 & 0 & 0 & 0 & 16 & 5.9 & 0 & 0 & 0 & 0 & 16 & 2 \\
\hline TJBGH & $1,2 \mathrm{a}, 2 \mathrm{c}, 3,16,24,10,28,42$ & 2 & 1.3 & 0 & 0 & 0 & 0 & 0 & 0 & 0 & 0 & 12 & 4.4 & 0 & 0 & 0 & 0 & 14 & 1.8 \\
\hline TJBJH & $1,2 \mathrm{a}, 2 \mathrm{c}, 3,16,24,10,14 \mathrm{a}, 28,42$ & 0 & 0 & 0 & 0 & 0 & 0 & 1 & 0.5 & 3 & 4.4 & 5 & 1.8 & 0 & 0 & 0 & 0 & 9 & 1.1 \\
\hline TJDGG & $1,2 \mathrm{a}, 2 \mathrm{c}, 3,16,24,17,10,28$ & 0 & 0 & 0 & 0 & 0 & 0 & 0 & 0 & 0 & 0 & 1 & 0.4 & 0 & 0 & 0 & 0 & 1 & 0.1 \\
\hline TJDGH & $1,2 \mathrm{a}, 2 \mathrm{c}, 3,16,24,17,10,28,42$ & 0 & 0 & 0 & 0 & 0 & 0 & 0 & 0 & 0 & 0 & 32 & 11.8 & 0 & 0 & 0 & 0 & 32 & 4 \\
\hline TKBGG & $1,2 \mathrm{a}, 2 \mathrm{c}, 3,16,24,26,10,28$ & 0 & 0 & 0 & 0 & 0 & 0 & 0 & 0 & 0 & 0 & 1 & 0.4 & 0 & 0 & 0 & 0 & 1 & 0.1 \\
\hline TKBGH & $1,2 \mathrm{a}, 2 \mathrm{c}, 3,16,24,26,10,28,42$ & 0 & 0 & 0 & 0 & 0 & 0 & 0 & 0 & 0 & 0 & 2 & 0.7 & 0 & 0 & 0 & 0 & 2 & 0.3 \\
\hline TKBJG & $1,2 \mathrm{a}, 2 \mathrm{c}, 3,16,24,26,10,14 \mathrm{a}, 28$ & 0 & 0 & 0 & 0 & 0 & 0 & 0 & 0 & 0 & 0 & 4 & 1.5 & 0 & 0 & 0 & 0 & 4 & 0.5 \\
\hline TKBJH & $1,2 \mathrm{a}, 2 \mathrm{c}, 3,16,24,26,10,14 \mathrm{a}, 28,42$ & 0 & 0 & 0 & 0 & 0 & 0 & 1 & 0.5 & 0 & 0 & 2 & 0.7 & 0 & 0 & 0 & 0 & 3 & 0.4 \\
\hline TKDJG & $1,2 \mathrm{a}, 2 \mathrm{c}, 3,16,24,26,17,10,14 \mathrm{a}, 28$ & 0 & 0 & 0 & 0 & 0 & 0 & 0 & 0 & 0 & 0 & 2 & 0.7 & 0 & 0 & 0 & 0 & 2 & 0.3 \\
\hline TLBDG & $1,2 \mathrm{a}, 2 \mathrm{c}, 3,9,14 \mathrm{a}, 28$ & 0 & 0 & 0 & 0 & 2 & 7.4 & 0 & 0 & 0 & 0 & 0 & 0 & 0 & 0 & 0 & 0 & 2 & 0.3 \\
\hline TLGJG & $1,2 \mathrm{a}, 2 \mathrm{c}, 3,9,11,10,14 \mathrm{a}, 28$ & 4 & 2.5 & 0 & 0 & 0 & 0 & 0 & 0 & 0 & 0 & 0 & 0 & 0 & 0 & 0 & 0 & 4 & 0.5 \\
\hline TLRJG & $1,2 \mathrm{a}, 2 \mathrm{c}, 3,9,3 \mathrm{ka}, 11,30,10,14 \mathrm{a}, 28$ & 2 & 1.3 & 0 & 0 & 0 & 0 & 0 & 0 & 3 & 4.4 & 0 & 0 & 0 & 0 & 0 & 0 & 5 & 0.6 \\
\hline TMGJG & $1,2 \mathrm{a}, 2 \mathrm{c}, 3,9,26,11,10,14 \mathrm{a}, 28$ & 0 & 0 & 0 & 0 & 0 & 0 & 3 & 1.4 & 0 & 0 & 1 & 0.4 & 0 & 0 & 0 & 0 & 4 & 0.5 \\
\hline TNRJJ & $1,2 \mathrm{a}, 2 \mathrm{c}, 3,9,24,3 \mathrm{ka}, 11,30,10,14 \mathrm{a}, 28,41$ & 9 & 5.7 & 4 & 16.7 & 0 & 0 & 17 & 7.7 & 4 & 5.9 & 2 & 0.7 & 0 & 0 & 0 & 0 & 36 & 4.5 \\
\hline TNRJK & $1,2 \mathrm{a}, 2 \mathrm{c}, 3,9,24,3 \mathrm{ka}, 11,30,10,14 \mathrm{a}, 28,41,42$ & 2 & 1.3 & 0 & 0 & 0 & 0 & 30 & 13.6 & 1 & 1.5 & 14 & 5.1 & 0 & 0 & 0 & 0 & 47 & 5.9 \\
\hline Total & & 158 & & 24 & & 27 & & 220 & & 68 & & 272 & & 20 & & 8 & & 797 & \\
\hline
\end{tabular}

${ }^{a}$ Lines tested were Thatcher lines with genes $L r 1, L r 2 a, L r 2 c, L r 3 a, L r 9, L r 16, L r 24, L r 26, L r 3 k a, L r 11, L r 17, L r 30, L r B, L r 10, L r 14 a, L r 18, L r 21, L r 28$, and winter wheat lines with genes $L r 41$, and $L r 42$.

b States of LA, AR, MS, AL, GA, FL, TE, SC, NC.

c States of VA, WV, MD, PA, DE, NJ, NY, MA, CT, RI, VT, NH, ME.

d States of MO, IL, KY, OH, IN, MI, WI

States of TX, OK, NM.

f States of KS, MO, IA, NE, CO.

g States of MN, ND, SD, WY, MT.

h State of CA.

i State of WA. 
In the southeastern states (area 1), 27 virulence phenotypes were found among the 158 single uredinial isolates tested (Table 1). Phenotypes MCRKG (19.0\%), TCRKG (10.8\%), and MCDSB (9.5\%) were the three most common phenotypes in this area. In the northeastern states (area $2)$, seven phenotypes, MBDSB (8.3\%), MCDSB (41.7\%), MDGJH (8.3\%), MFBGJ (8.3\%), TCRKG (8.3\%), TFBJG (8.3\%), and TNRJJ (16.7\%), accounted for all 24 isolates in this area. In the Ohio Valley states of area 3, 12 virulence phenotypes were found among the 27 isolates tested. Phenotypes TDBGG (14.8\%), MBDSB (11.1\%), and MFPSC (11.1\%) were the three most common phenotypes.

In the southern Great Plains of Texas and Oklahoma (area 4), 30 virulence phenotypes were found among the 220 isolates tested (Table 1). Phenotypes TDBGH (14.5\%), TNRJK (13.6\%), and MCDSB (11.4\%) were the three most common phenotypes. In the central Great Plains of Kansas and Nebraska (area 5), 16 virulence phenotypes were found among the 68 isolates tested. Phenotypes TDBGH (25.0\%), MCDSB (13.2\%), and TDBGG $(11.8 \%)$ were the three most common phenotypes in this area. Virulence phenotypes SBDBG and SBDDB were found in collections of leaf rust from T. cylindrica in areas 4 and 5. In the northern Great Plains of Minnesota, South Dakota, and North Dakota (area 6), 44 phenotypes were found among the 272 isolates that were tested. Phenotypes TJDGH (11.8\%), TDBGH
(11.0\%), and MFPSC (9.9\%) were the three most common phenotypes in this area.

In California (area 7), six virulence phenotypes, MBDSB (35.0\%), MBSJB (10.0\%), MCDSB (5.0\%), MCDSG (10.0\%), MFPSC (20.0\%), and MHDSB $(20.0 \%)$, accounted for all 20 isolates that were tested. In Washington State (area 8), four virulence phenotypes, MBBJG (25.0\%), MBDSB (12.5\%), MBJJG (50.0\%), and MCDSG (12.5\%), accounted for all eight isolates that were tested.

Virulence frequencies. Frequencies of virulence to $L r$ genes differed among the regional populations of $P$. triticina in the United States (Table 2). Virulences to genes $L r 1, L r 3$, and $L r 10$ were at over $90 \%$ in all areas. Virulence to $L r 21$ was not found in any region. Virulence to genes $L r 2 a$ and $L r 2 c$ was present in all regions except for areas 7 and 8, and was at the highest frequency in area 6 at $80.1 \%$. Virulence to gene $\operatorname{Lr} 16$ was not present in areas 2 and 8 , occurred at low frequencies in areas $1,3,4$, and 5, and was most common in area 6 at $43.0 \%$. Virulence to $\operatorname{Lr} 24$ was not found in area 8 , and occurred at intermediate frequencies in the other areas with the highest frequency of $68.0 \%$ in area 6 . Virulence to $\operatorname{Lr} 26$ was found in all areas at intermediate frequencies with the highest frequency of $66.7 \%$ in area 2 . Virulence to gene $L r 3 k a$ was not found in area 8 , and was at intermediate frequencies in the other areas with the highest frequency of $60.1 \%$ in area 1 . Virulence to gene $\mathrm{Lrll}$ was at low to intermediate frequencies in all areas with the highest frequency of $64.6 \%$ in area 1 . Virulence to $\operatorname{Lr} 17$ was present in all areas, and was at the highest frequency in area 7 at $100 \%$. Virulence to Lr30 was not found in area 8, and was at intermediate frequencies in the other areas with the highest frequency in area 1 at $57.6 \%$. Virulence to gene $\operatorname{LrB}$ occurred in all areas with the highest frequency of $90.0 \%$ in area 7. Virulence to $L r 14 a$ was found in all areas with the highest frequency of $100 \%$ in area 7 . Virulence to Lr18 was not found in areas 7 and 8, was at low frequencies in areas 2, 3, 4, 5, and 6, and was at $44.9 \%$ in area 1 . Virulence to $\operatorname{Lr} 28$ was at intermediate frequencies in all regions, with the highest frequency of $87.5 \%$ in area 8 . Virulence to $\mathrm{Lr} 41$ was not found in areas 2,7 , and 8 , and was at low to intermediate frequency in the other regions with the highest frequency of $21.4 \%$ in area 5. Virulence to $\mathrm{Lr} 42$ was not found in area 8 , and was at intermediate frequency in the other regions with the highest frequency of $55.5 \%$ in area 6.

\section{DISCUSSION}

In 2005, phenotypes TDBGH with virulence to $L r 24$ and MFPSC with virulence to $L r 24, L r 26$, and $L r 17 a$ were among the three most common leaf rust phenotypes in the United States. TDBGH occurred mostly in the hard red winter wheat areas 4 and 5, and also in the hard red spring wheat area 6. MFPSC occurred in areas 3, $4,5,6$, and 7 . Both phenotypes have in-

Table 2. Number and frequency (\%) of isolates of Puccinia triticina in the United States in 2005 virulent to 20 lines of wheat with single resistance genes for leaf rust resistance

\begin{tabular}{|c|c|c|c|c|c|c|c|c|c|c|c|c|c|c|c|c|c|c|}
\hline \multirow{2}{*}{$\begin{array}{l}\text { Resistance } \\
\text { gene }\end{array}$} & \multicolumn{2}{|c|}{ Area $1^{a}$} & \multicolumn{2}{|c|}{ Area $2^{b}$} & \multicolumn{2}{|c|}{ Area $3^{c}$} & \multicolumn{2}{|c|}{ Area 4d } & \multicolumn{2}{|c|}{ Area $5^{\mathrm{e}}$} & \multicolumn{2}{|c|}{ Area $6^{\mathrm{e}}$} & \multicolumn{2}{|c|}{ Area $7^{f}$} & \multicolumn{2}{|c|}{ Area $8^{\text {h }}$} & \multicolumn{2}{|c|}{ Total } \\
\hline & \# & $\%$ & \# & $\%$ & \# & $\%$ & \# & $\%$ & \# & $\%$ & \# & $\%$ & \# & $\%$ & \# & $\%$ & $\#$ & $\%$ \\
\hline$\overline{L r l}$ & 157 & 99.5 & 24 & 100 & 27 & 100 & 220 & 100 & 68 & 100 & 271 & 99.5 & 20 & 100 & 8 & 100 & 795 & 99.7 \\
\hline $\operatorname{Lr} 2 a$ & 70 & 44.3 & 8 & 33.3 & 17 & 63 & 134 & 60.9 & 47 & 69.1 & 218 & 80.1 & 0 & 0 & 0 & 0 & 494 & 62 \\
\hline$L r 2 c$ & 70 & 44.3 & 8 & 33.3 & 17 & 63 & 134 & 60.9 & 47 & 69.1 & 218 & 80.1 & 0 & 0 & 0 & 0 & 494 & 62 \\
\hline Lr3 & 157 & 99.4 & 24 & 100 & 27 & 100 & 215 & 97.7 & 66 & 97.1 & 270 & 99.3 & 20 & 100 & 8 & 100 & 787 & 98.7 \\
\hline $\operatorname{Lr} 9$ & 21 & 13.3 & 4 & 16.7 & 4 & 14.8 & 58 & 26.4 & 12 & 17.6 & 23 & 8.5 & 0 & 0 & 0 & 0 & 122 & 15.3 \\
\hline Lrl6 & 6 & 3.8 & 0 & 0 & 2 & 7.4 & 2 & 0.9 & 5 & 7.4 & 117 & 43 & 4 & 20 & 0 & 0 & 136 & 17.1 \\
\hline Lr24 & 37 & 23.4 & 10 & 41.7 & 16 & 59.3 & 155 & 70.5 & 40 & 58.8 & 185 & 68 & 4 & 20 & 0 & 0 & 447 & 56.1 \\
\hline $\operatorname{Lr} 26$ & 82 & 51.9 & 16 & 66.7 & 10 & 37 & 88 & 40 & 16 & 23.5 & 58 & 21.3 & 11 & 55 & 1 & 12.5 & 282 & 35.4 \\
\hline Lr3ka & 95 & 60.1 & 6 & 25 & 5 & 18.5 & 84 & 38.2 & 15 & 22.1 & 48 & 17.6 & 6 & 30 & 0 & 0 & 259 & 32.5 \\
\hline Lr11 & 102 & 64.6 & 8 & 33.3 & 2 & 7.4 & 54 & 24.5 & 10 & 14.7 & 22 & 8.1 & 2 & 10 & 4 & 50 & 204 & 25.6 \\
\hline $\operatorname{Lr} 17$ & 38 & 24.1 & 12 & 50 & 10 & 37 & 96 & 43.6 & 23 & 33.8 & 134 & 49.3 & 20 & 100 & 6 & 75 & 339 & 42.5 \\
\hline Lr30 & 91 & 57.6 & 6 & 25 & 5 & 18.5 & 82 & 37.3 & 15 & 22.1 & 48 & 17.6 & 4 & 20 & 0 & 0 & 251 & 31.5 \\
\hline$L r B$ & 35 & 22.2 & 12 & 50 & 10 & 37 & 90 & 40.9 & 19 & 27.9 & 62 & 22.8 & 18 & 90 & 2 & 25 & 248 & 31.1 \\
\hline Lrlo & 157 & 99.4 & 24 & 100 & 25 & 92.6 & 214 & 97.3 & 66 & 97.1 & 268 & 98.5 & 20 & 100 & 8 & 100 & 782 & 98.1 \\
\hline Lr14a & 144 & 91.1 & 24 & 100 & 21 & 77.8 & 169 & 76.8 & 43 & 63.2 & 140 & 51.5 & 20 & 100 & 8 & 100 & 569 & 71.4 \\
\hline Lr18 & 71 & 44.9 & 2 & 8.3 & 2 & 7.4 & 3 & 1.4 & 2 & 2.9 & 3 & 1.1 & 0 & 0 & 0 & 0 & 83 & 10.4 \\
\hline $\operatorname{Lr} 21$ & 0 & 0 & 0 & 0 & 0 & 0 & 0 & 0 & 0 & 0 & 0 & 0 & 0 & 0 & 0 & 0 & 0 & 0 \\
\hline Lr28 & 122 & 77.2 & 12 & 50 & 17 & 63 & 133 & 60.5 & 47 & 69.1 & 220 & 80.9 & 2 & 10 & 7 & 87.5 & 560 & 70.3 \\
\hline Lr41 & 11 & 7.0 & 4 & 16.7 & 0 & 0 & 47 & 21.4 & 5 & 7.4 & 16 & 5.9 & 0 & 0 & 0 & 0 & 83 & 10.4 \\
\hline Lr42 & 22 & 13.9 & 2 & 8.3 & 7 & 25.9 & 96 & 43.6 & 26 & 38.2 & 151 & 55.5 & 4 & 20 & 0 & 0 & 308 & 38.6 \\
\hline Total & 158 & & 24 & & 27 & & 220 & & 68 & & 272 & & 20 & & 8 & & 797 & \\
\hline
\end{tabular}

a States of LA, AR, MS, AL, GA, FL, TE, SC, NC.

b States of VA, WV, MD, PA, DE, NJ, NY, MA, CT, RI, VT, NH, ME.

c States of MO, IL, KY, OH, IN, MI, WI.

d States of TX, OK, NM.

e States of KS, MO, IA, NE, CO.

${ }^{f}$ States of MN, ND, SD, WY, MT.

g State of CA.

h State of WA. 
creased in frequency since 2004 due to virulence to $L r 24$ that is common in many hard red winter wheat cultivars in areas 4 and 5 (J. A. Kolmer and D. L. Long, unpublished data). MCDSB, which was also a common race in 2004, occurred in all areas except for 3 and 8. MCDSB and MFPSC are both virulent to genes $\operatorname{Lr} 17 a$ and Lr26. Many hard red winter wheat cultivars in areas 4 and 5 that are derived from 'Jagger' have Lr17a (J. A. Kolmer and D. L. Long, unpublished data), and many soft red winter wheat cultivars grown in areas 1 and 3 have $\operatorname{Lr} 26$ (12).

The selective effect of the leaf rust resistance genes present in the different classes of wheat are also reflected in the most common $P$. triticina virulence phenotypes in each area. In area 1, where soft red winter wheat is grown, the most common phenotype was MCRKG, which has virulence to genes Lr11, Lr18, and Lr26. These genes are common in the soft red winter wheat cultivars in this area (12). MCRKG was also the most common phenotype in this area in 2004. Phenotype TCRKG is also virulent to genes $\operatorname{Lrll}, \operatorname{Lr} 18$, and $L r 26$. Phenotypes with virulence to $L r 3 k a$, Lr11, Lr30, and Lr18 were most common in area 1 . In area 4 , of the two most common phenotypes, TDBGH is virulent to $L r 24$, and TNRJK is virulent to $L r 9, L r 24$, and $L r 41$. The hard red winter wheat cultivars Thunderbolt and Overley, and cultivars derived from these wheats, may have Lr41. Phenotypes with virulence to $\operatorname{Lr} 9$ and $\operatorname{Lr} 41$ were most common in area 4. Phenotype TDBGH was common in areas 4,5 , and 6 , being wind dispersed throughout the Great Plains region. Phenotype MCDSB was common in areas 4 and 5, due to virulence to $L r 17 a$, which is present in 'Jagger' and other cultivars in these areas. In area 6 , the most common phenotype, TJDGH, had virulence to $L r 2 a$ and Lr16. Both of these genes are common in the hard red spring wheat grown in this region (19). MHDSB, with virulence to Lr16, was also common in area 6. Phenotype MFPSC, also common in area 6, likely originated in areas 4 and 5 , and was wind dispersed into area 6. Phenotypes with virulence to $\operatorname{Lr} 2 a, \operatorname{Lr} 2 c, \operatorname{Lr} 16, \operatorname{Lr} 24$, and $L r 42$ were most common in area 6 .

Phenotypes SBDBG and SBDDG were collected from goat grass in Texas, Oklahoma, and Kansas. These phenotypes are unique in that they are avirulent to Lr3. Currently, these phenotypes are rarely found on common wheat, although these were among the most common leaf rust phenotypes on wheat in the United States and Canada in the 1930s $(5,6,9)$. These phenotypes rapidly decreased in frequency with the release of winter cultivars with Lr3 in the 1940s (9).

Since 2004, there has been a large shift in $P$. triticina virulence phenotypes in the United States. Of the most common regional phenotypes in 2005, only MCRKG,
MCDSB, TNRJK, and MHDSB were also common at a regional level in 2004 (13). Phenotypes such as TDBGH, TDBGG, and TJDGH, with virulence to $L r 24$ and avirulence to $L r 14 a$, have rapidly increased in frequency in areas 3, 4, 5, and 6. These phenotypes are also unique since they are virulent to $\mathrm{Lrl}$, but produce a low mesothetic IT to a second gene(s) that is also present in the Thatcher line with $\operatorname{Lrl}$ (13). Since $L r 24$ is present in a number of hard red wheat cultivars and breeding lines, it is likely that phenotypes with virulence to $L r 24$ will persist in the $P$. triticina population for at least the immediate future. Overall, phenotypes with virulences to genes Lr16, Lr24, Lr3ka, Lr30, Lr28, and $\mathrm{Lr} 42$ have markedly increased in frequency since 2004 (13). This is mostly due to selection of phenotypes with virulence to $L r 24$ and Lr16. Phenotypes avirulent to Lr14a have decreased in frequency since 2004.

Genes Lr2a, Lr9, Lr10, Lr11, Lr14a, $L r 16, L r 17, L r 24, L r 26$, and $L r 41$ are present in the winter and spring wheat cultivars grown in the United States. Virulence to all of these individual genes in the $P$. triticina population is at intermediate to high frequencies. None of these genes by themselves would condition a high level of resistance. Certain combinations of seedling genes may condition high levels of resistance in widely grown wheat cultivars for a few years. However, given the diversity of leaf rust virulence phenotypes and the selective effects of resistance genes, it would be expected that virulent phenotypes in the $P$. triticina population would soon increase to damaging levels.

The $P$. triticina population in the United States is highly diverse, with many virulence phenotypes present. The widespread cultivation of wheat cultivars with seedling resistance genes has inevitably lead to the selection and increase of phenotypes with virulence to the resistance genes. A large population of $P$. triticina survives the winter on susceptible winter wheats in the southern United States, thus creating a large reservoir for virulence mutations and subsequent selection by cultivars with seedling resistance $L r$ genes. Greater use of germplasm with nonspecific adult plant resistance genes Lr34 and Lr46 (24) in the winter wheats grown in the United States would increase the overall frequency of cultivars with effective resistance, and also help reduce the size of the overwintering $P$. triticina population. In a recent survey of current and historical winter wheats, none of the soft red winter wheats and very few of the hard red winter wheats had the marker allele associated with the adult plant resistance gene Lr34 when tested with a diagnostic PCR marker (J. A. Kolmer, unpublished data). By making crosses with germplasm that carry Lr34 and Lr46, and selecting based on markers and rust phenotypes, it should be possible to im- prove leaf rust resistance in the winter wheats.

\section{LITERATURE CITED}

1. Caldwell, R. M., Kraybill, H. R., Sullivan, J. T., and Compton, L. E. 1934. Effect of leaf rust (Puccinia triticina) on yield, physical characters, and composition of winter wheats. J. Agric. Res. 48:1049-1071.

2. Chester, K. S. 1946. The Nature and Prevention of the Cereal Rusts as Exemplified in the Leaf Rust of Wheat. Chronica Botanica, Waltham, MA.

3. Dyck, P. L., and Samborski, D. J. 1968. Genetics of resistance to leaf rust in the common wheat varieties Webster, Loros, Brevit, Carina, Malakof and Centenario. Can. J. Genet. Cytol. 10:7-17.

4. Herrera-Foessel, S. A., Singh, R. P., HuertaEspino, J., Crossa, J., Yuen, J., and Djurle, A. 2006. Effect of leaf rust on grain yield and yield traits of durum wheats with race-specific and slow rusting resistance to leaf rust. Plant Dis. 90:1065-1072.

5. Johnson, T. 1956. Physiologic races of leaf rust of wheat in Canada 1931 to 1955. Can. J. Agric. Sci. 36:323-332.

6. Johnston, C. O., Caldwell, R. M., Compton, L E., and Browder, L. E. 1968. Physiologic races of Puccinia recondita f. sp. tritici in the United States from 1926 through 1960. U.S. Dep. Agric. Tech. Bull. 1393:1-18

7. Khan, M. A., Trevathan, L. E., and Robbins, J. T. 1997. Quantitative relationship between leaf rust and wheat yield in Mississippi. Plant Dis. 81:769-772.

8. Kolmer, J. A. 1991. Phenotypic diversity in two populations of Puccinia recondita f. sp. tritici in Canada during 1931-1987. Phytopathology 81:311-315.

9. Kolmer, J. A. 1991. Evolution of distinct populations of Puccinia recondita f. sp. tritici in Canada. Phytopathology 81:316-322.

10. Kolmer, J. A. 1999. Virulence dynamics, phenotypic diversity, and virulence complexity in two populations of Puccinia triticina in Canada from 1987-1997. Can. J. Bot. 77:333338.

11. Kolmer, J. A. 2001. Physiologic specialization of Puccinia triticina in Canada in 1998. Plant Dis. 85:155-158.

12. Kolmer, J. A. 2003. Postulation of leaf rust resistance genes in selected soft red winter wheats. Crop Sci. 43:1266-1274.

13. Kolmer, J. A., Long, D. L., and Hughes, M. E. 2006. Physiologic specialization of Puccinia triticina on wheat in the United States in 2004 Plant Dis. 90:1219-1224.

14. Long, D. L., and Kolmer, J. A. 1989. A North American system of nomenclature for $P u c$ cinia recondita f. sp. tritici. Phytopathology 79:525-529.

15. Long, D. L., Leonard, K. J., and Hughes, M. E. 2000. Virulence of Puccinia triticina on wheat in the United States from 1996 to 1998. Plant Dis. 84:1334-1341.

16. Long, D. L., Leonard, K. J., and Roberts, J. J. 1998. Virulence and diversity of wheat leaf rust in the United States in 1993 to 1995. Plant Dis. 82:1391-1400.

17. Marasas, C. N., Smale, M., and Singh, R. P. 2004. The economic impact in developing countries of leaf rust resistance breeding in CIMMYT-related spring bread wheat. Economics Program Paper 04-01. CIMMYT, Mexico, D.F.

18. McIntosh, R. A., Yamazaki, Y., Devos, K. M., Dubcovsky, J., Rogers, J., and Appels, R. 2005. Catalogue of Gene Symbols for Wheat. KOMUGI Integrated WheatScience Database. Published online. Accessed 3/6/2007.

19. Oelke, L. M., and Kolmer, J. A. 2004. Characterization of leaf rust resistance in hard red 
spring wheat cultivars. Plant Dis. 88:11271133.

20. Roelfs, A. P., Singh, R. P., and Saari, E. E. 1992. Rust Diseases of Wheat: Concepts and methods of disease management. CIMMYT, Mexico, D.F

21. Samborski, D. J., and Dyck, P. L. 1968. Inheritance of virulence in wheat leaf rust on the standard differential wheat varieties. Can. J. Genet. Cytol. 10:24-32.

22. Singh, R. P. 1991. Pathogenicity variations of Puccinia recondita f. sp. tritici and $P$. graminis f. sp. tritici in wheat-growing areas of Mexico during 1988 and 1989. Plant Dis. 75:790-794.

23. Singh, R. P., Huerta-Espino, J., Pfeiffer, W., and Figueroa-Lopez, P. 2004. Occurrence and impact of a new leaf rust race on durum wheat in northwestern Mexico from 2001 to 2003. Plant Dis. 88:703-708.

24. Singh, R. P., Huerta-Espino, J., and Rajaram, S. 2000. Achieving near-immunity to leaf rus and stripe rust in wheat by combining slow rusting resistance genes. Acta Phytopathol. Entomol. 35:133-139. 